\title{
Characterization and Laboratory-Scale Treatment of Municipal Drainage Wastewater of Khulna, Bangladesh
}

\author{
Md Rasel Sheikh1, Md Saiful Islam² \\ ${ }^{1}$ Department of Disaster Resilience and Engineering, Patuakhali Science and Technology University, Patuakhali, Bangladesh \\ ${ }^{2}$ Department of Civil Engineering, Khulna University of Engineering and Technology, Khulna, Bangladesh \\ Email: raselsheikh55@gmail.com, saifulkuet92@gmail.com
}

How to cite this paper: Sheikh, M.R. and Islam, M.S. (2018) Characterization and Laboratory-Scale Treatment of Municipal Drainage Wastewater of Khulna, Bangladesh. Journal of Water Resource and Protection, 10, 979-993.

https://doi.org/10.4236/jwarp.2018.1010057

Received: August 14, 2018

Accepted: October 26, 2018

Published: October 29, 2018

Copyright ( $\odot 2018$ by authors and Scientific Research Publishing Inc. This work is licensed under the Creative Commons Attribution International License (CC BY 4.0).

http://creativecommons.org/licenses/by/4.0/ (c) (i) Open Access

\begin{abstract}
The study was conducted to characterize and perform laboratory-scale treatment of municipal drainage wastewater of Khulna, Bangladesh. Wastewater samples were collected from three different points of existing urban drain outlets into the Mayur River around Khulna. Laboratory testing shows the $\mathrm{BOD}_{5}$ and COD concentration of wastewater samples varied from $57-226 \mathrm{mg} / \mathrm{l}$ and $320-435 \mathrm{mg} / \mathrm{l}$, respectively, and the total dissolved solids ranged from 1800 - $2525 \mathrm{mg} / \mathrm{l}$. Therefore, a laboratory-scale treatment technology was developed to treat this wastewater. Treatment technologies adopted were primary sedimentation, followed by aeration, chemical precipitation and filtration. In treated wastewater, $\mathrm{BOD}_{5}, \mathrm{COD}$ and TDS were found to be in the range of $40-115 \mathrm{mg} / \mathrm{l}, 160-256 \mathrm{mg} / \mathrm{l}$ and $1356-1500 \mathrm{mg} / \mathrm{l}$, respectively. These test results suggest that the performance of laboratory-scale treatment plant was not adequate to fulfil the acceptable limit (ECR'97) for safe disposal into surface water bodies. Due to poor quality of effluents, modification of laboratory-scale treatment plant was made by an activated sludge process followed by granular media filtration. The final $\mathrm{BOD}_{5}$, COD TDS and TSS concentration of effluents was found to be $1.38-9.8 \mathrm{mg} / \mathrm{l}, 32-192 \mathrm{mg} / \mathrm{l}, 590$ $1667 \mathrm{mg} / \mathrm{l}$, and $35-95 \mathrm{mg} / \mathrm{l}$ respectively, which satisfy ECR'97 standard limits for safe disposal into inland water bodies.
\end{abstract}

\section{Keywords}

Drainage Wastewater, Laboratory-Scale Treatment, Activated Sludge Process, Granular Filter Media, Effluents

\section{Introduction}

As city populations are growing in many developing countries and inhabitants 
look for better living standards, huge amounts of freshwater are converted to domestic, commercial, and industrial sectors, which creates larger volumes of wastewater [1] [2]. Consequently, as UNESCO reported in 2003, more than $80 \%$ of the wastewater generated in developing countries like Bangladesh is disposed untreated into the surface water bodies nearby, and around $50 \%$ of the population have no way to access fresh water other than polluted water sources [3]. However, using urban wastewater in agriculture can conserve water, recycle nutrients, ensure reliable water supply to farmers, and prevent pollution of surface water that would otherwise be used for the disposal of wastewater [4]. The use of wastewater for irrigation has now become a reality rather than a matter of choice. As Huibers and Van Lier reported [5], such a reality exists not only in arid and semi-arid regions, but also in humid areas where seasonal water storage occurs. Some researchers predicted that at least 3.5 Mega-hectors are irrigated globally without treatment, partly treated, diluted or treated wastewater [6]. For different crop production, farmers in Khulna area, are using this wastewater as their available water source, which diverts this wastewater in a partially treated, diluted or untreated form. This exercise can severely damage human health and the environment, not only with related pathogens, but also heavy metals and other unwanted wastewater components [7].

Khulna is the third largest city of Bangladesh and the city has population of around 663,342 in 2011 and total area is about 59.57 square kilometers [8]. According to a land use survey undertaken for the preparation of the Khulna Master Plan, about $79 \%$ of the city area is classified as "built-up" and the remaining $21 \%$ is mostly covered by agricultural land [9]. Due to the regular activity of city dwellers and rapid urbanization, a huge amount of grey water is being produced. It has been noticed that the drainage wastewater is mostly generated from the water used in households, restaurants, educational institutes, offices, hospitals and industries in the city. Moreover, the average annual rainfall of Khulna is 1800 millimeters $(\mathrm{mm})$ and approximately $87 \%$ of the annual average rainfall occurs between May and October [10]. This water flows through numerous concrete and earthen open drains and finally drains to the peripheral rivers and canals without treatment. The drains are also somewhere directly connected with the septic tank system, which has severe negative impact on environment especially on surface water bodies. Because of broken and uncovered drains, sometimes different solid wastes such as food wastes, garden wastes, are disposed into the drain, which causes blockage of drains and increases mosquito breeding. Mayur River is one of the most important parts of Khulna where large amounts of drainage water are released. Many poor farmers living in the western peripheral of Khulna put polluted wastewater in their agricultural fields. However, the use of this unconventional water for irrigation by poor farmers and local people is not yet documented. Birks and Hills (2007) [11] reported that, microbiological characteristics of municipal drainage wastewater have received much attention in recent research. Khulna City Corporation (KCC) has its own 
drainage network system, which is not well-developed. Wastewater produced in the KCC area flows through numerous concrete and earthen drains, which finally lead to the nearby water bodies, i.e. the Mayur and Rupsha rivers. About 18 big and small canals and drains carry effluents from the KCC area to the Mayur River, which is placed at the western part of the city. This drainage wastewater is now polluting the river water, because treatment facilities are not yet established in KCC.

A study on wastewater treatment technologies is a very important aspect of water pollution studies. Although, many research works have been carried out on water pollution, but a few number of research can be found on development of wastewater treatment technology particularly for Khulna municipal drainage wastewater. Therefore, this study attempts to characterize and develop a laboratory-scale drainage wastewater treatment plant to understand issues of large-scale implementation to protect surface water bodies around Khulna municipal area.

\section{Materials and Methods}

\subsection{Research Design}

This study was based on a laboratory research design, because the study focused on investigating the drainage wastewater quality analysis and its treatment. At first, a field visit was carried out in various drainage outlets of KCC, mainly the Daulatpur to Gollamari bazar areas. Then the methods outlined in the Standard Methods for the Examination of water and wastewater [12] were followed for the analyses of collected wastewater samples for all the physical and chemical parameters. TDS and TSS were determined by using filter paper and oven. After filtering the sample by the filter paper, it was placed into oven at $105^{\circ} \mathrm{C}$ for 24 hours. Conductivity meter was used for the determination of electrical conductivity and $\mathrm{pH}$ meter $(\mathrm{HACH}$, sension 2$)$ was used for determination of $\mathrm{pH}$. Turbidity and color were measured with a Partech DRT 100B Turbidity meter and a color comparator respectively. For the determination of sulphate $\left(\mathrm{SO}_{4}\right)$ and $\mathrm{Ni}$ trate $\left(\mathrm{NO}_{3}\right)$, Sulfa-Ver 4 reagent and Nitra-Ver 5 reagent were used. EDTA was used in burette for titration in hardness test and Eri-chrom black T (EDT) was used as the reagent and titrated until the blue colour formed. DO bottle and DO meter ( $\mathrm{HACH}, \mathrm{HQ} 40 \mathrm{~d}$ ) were required for laboratory analysis of $\mathrm{BOD}_{5}$ and 5 days were needed for the test. For determination of $\mathrm{COD}, \mathrm{K}_{2} \mathrm{Cr}_{2} \mathrm{O}_{7}$ was taken in the pipette and ferrion indicator was used as reagent and titrated until the radish color formed. Total coliform and faecal coliform were measured by the membrane filtration technique by using XMG Agar reagent into a petri-dish. Therefore, a laboratory-scale wastewater treatment plant was developed and treatment efficiency of the plant was monitored. Finally, paying attention to effluent quality of laboratory-scale treatment plant, modification has been made for better performance.

\subsection{Sources of Drainage Wastewater Sample Collection}

There are mainly ten outlets from which the wastewater releases into the Mayur River. The information regarding the drain outlets into the Mayur River and 
sampling locations are shown in Figure 1. Among 10 drain outlets, wastewater samples were collected from drain outlet 2 (Goalkhali, Bastuhara colony), 3 (Boyra Shahanghat bridge) and 7 (Gallamari, Gallamari bridge) for raw wastewater quality testing during December, January and April respectively. In addition, around Khulna city, during December to May farmers are facing freshwater scarcity for irrigation purpose [13]. However, the wastewater samples were collected from 50 to 100 feet ahead of drain outfall. The collected wastewater samples were analyzed individually. Drain outlet- 2 and outlet- 3 get water from almost domestic wastewater because this outlet passes through residential area including huge slaughter houses and there was no industrial and activity around outlet- 2 and outlet-3. Moreover, this area has some clinics and hospitals and plastic recycling factories. Drain outlet-7 carries wastewater from residential areas, some factories and markets as well. This wastewater is also dumped directly into open channels after generation. Because of these highly contaminated domestic wastewaters, market wastewater and factory related wastewater of these three-drain outlets were considered as sampling points for this study. Table 1 illustrates details about sampling station including drain outlets, sample ID and location.

Table 1. Details of sampling station.

\begin{tabular}{lccccc}
\hline Sample ID & Drain outlet & Area, location & Latitude & Longitude & Elevation (m) \\
\hline Sample I & 2 & Goalkhali, Bastuhara colony & $22^{\circ} 50^{\prime} 54.96^{\prime \prime} \mathrm{N}$ & $89^{\circ} 30^{\prime} 47.37^{\prime \prime} \mathrm{E}$ & 3.0 \\
Sample II & 3 & Boyra Shahanghat bridge & $22^{\circ} 49^{\prime} 35.48^{\prime \prime} \mathrm{N}$ & $89^{\circ} 31^{\prime} 46.76^{\prime \prime} \mathrm{E}$ & 4.6 \\
Sample III & 7 & Gallamari, Gallamari bridge & $22^{\circ} 48^{\prime} 3.75^{\prime \prime} \mathrm{N}$ & $89^{\circ} 32^{\prime} 25.62^{\prime \prime} \mathrm{E}$ & 4.0 \\
\hline
\end{tabular}

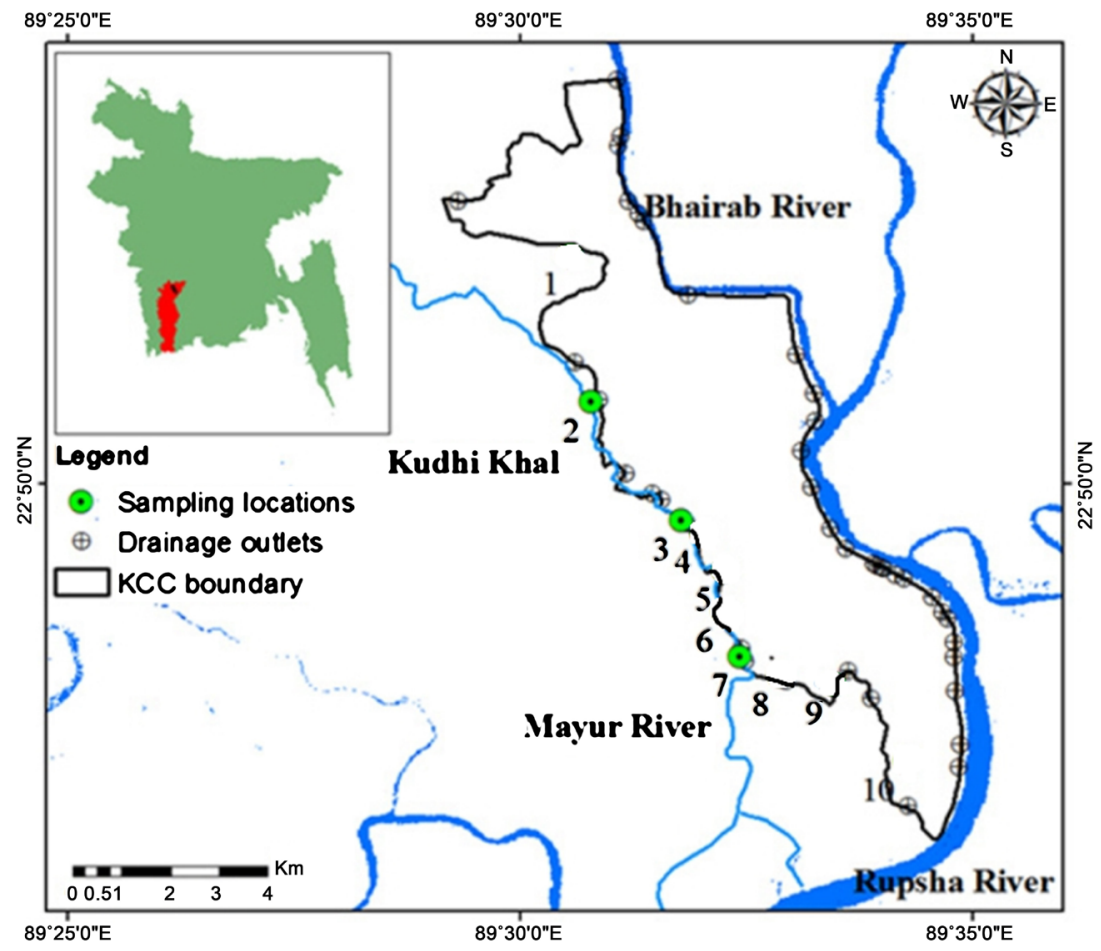

Figure 1. Sampling stations over Mayur River [13]. 


\subsection{Sampling Size and Sampling Procedure}

The KCC drain outlets were the potential sources of drainage wastewater sample collection of the study. Three drain outlets (No. 2, 3 and 7) were taken with random sampling from total ten drain outlets, mentioned in Table 1 and Figure 1 , as raw wastewater sampling stations. From every sampling station, total three samples were collected with special care. In December 2015, one wastewater sample from each sampling station was collected for laboratory testing and same procedures were followed for month of January and April 2016. New plastic "Jerry Can" of 20 litter capacity with hard plastic screw cap was used for wastewater sample collection. The can was properly cleaned before using and washed 2 - 3 times before sampling. Wastewater samples were collected from the midpoint of the trunk drains by dipping each sample Jerry Can approximately 15 $20 \mathrm{~cm}$ below the water surface, opening the Jerry Can, allowing it to fill in, then closing each Jerry Can with its cap under water. Wastewater samples were collected and transported to the laboratory on the same day. The samples were then preserved in a refrigerator at about $4^{\circ} \mathrm{C}$ until analysis. In all analyses samples were measured at dry weather conditions.

\subsection{Drainage Wastewater Treatment Techniques and Tools}

Wastewater treatment consists of applying known technology to improve or upgrade the quality of wastewater. This study follows collecting the wastewater samples and subjecting the wastewater to various treatment processes, as discussed below:

1) To identify the treatment units needed for the development of laboratory-scale treatment plant, the physical, chemical and biological characteristics of wastewater were investigated in the laboratory. After the laboratory tests of DO, $\mathrm{BOD}_{5}, \mathrm{COD}, \mathrm{TSS}, \mathrm{TDS}, \mathrm{NO}_{3}, \mathrm{SO}_{4}, \mathrm{pH}$, Conductivity, Color, Turbidity, and Coliforms of raw wastewater samples (three samples from each sites) and analyze secondary data, the design criteria were set for the treatment units. Based on the developed criteria, a laboratory-scale drainage wastewater treatment plant was constructed in the laboratory (Figure 2).

2) In this research work, a bar screen was used which consists of $5 \mathrm{~mm} \times 5 \mathrm{~mm}$ steel wire mess to cover up the rectangular primary sedimentation tank. The incoming wastewater passed through the bars or screens and the accumulated material was removed manually before colloguing the screen.

3) For laboratory-scale study, a 45-litter capacity plastic rectangular container was used as primary clarifier. The size of the container was 20 inches in length, 15 inches in wide and 10 inches in height with 2-inch free board (Figure 2(a)). The detention time was fixed to 2 hours for the sedimentation of settle able materials. In every batch of treatment, 40 liters of wastewater sample entered the chamber for 2 hours, and a path was made from the bottom of the rectangular tank to remove sludge that accumulated in this stage of treatment.

4) A 20 " $\times 15^{\prime \prime} \times 10$ " size plastic tank (Figure $2(\mathrm{~b})$ ) was used as an ation 
chamber and a mechanical device (Air blower: SP-780 model Super Pump) was used to support a continuous source of oxygen. The chamber also made with a 2-inch freeboard for preventing overflow. Aeration to activate microorganism, was done for 24 hours with 2 hours detention time. After the completion of aeration, an optimum alum dose of $70 \mathrm{mg} / \mathrm{L}$ was added for chemical precipitation after being determined in the laboratory. Manual steering was done for complete mixing with 30 minutes intervals for 2 hours, and then sample was kept at rest for another 2 hours for settling down of sludge. Sludge was collected from the bottom of the chamber through gate valve that was incorporated for regulation of flow.

5) Chemical precipitation and granular filtration incorporated for phosphorous and nutrient removal purpose. Up-flow roughing filter retains the floc generated from chemical precipitation. After roughing filtration, the effluents passed through sand filter for nitrogen and pathogenic bacteria removal. Roughing filter and sand filter were made with a 10 " $\times 15^{\text {" }} \times 10^{\text {" }}$ sized (Figure 2(c) and Figure 2(d)) chamber full of brick khoa (crushed brick) and Sylhet sand. The brick khoa used for roughing filtration was $2 \mathrm{~mm}$ to $40 \mathrm{~mm}$ in size. Similarly, the effective size of sand for sand filtration was $0.45 \mathrm{~mm}$ to $1.5 \mathrm{~mm}$. The chambers also consisted with a 2-inch freeboard for preventing overflow.

6) The collected raw wastewater sent into the sedimentation tank, which passed through a connecting hose pipe into the aeration tank. The wastewater

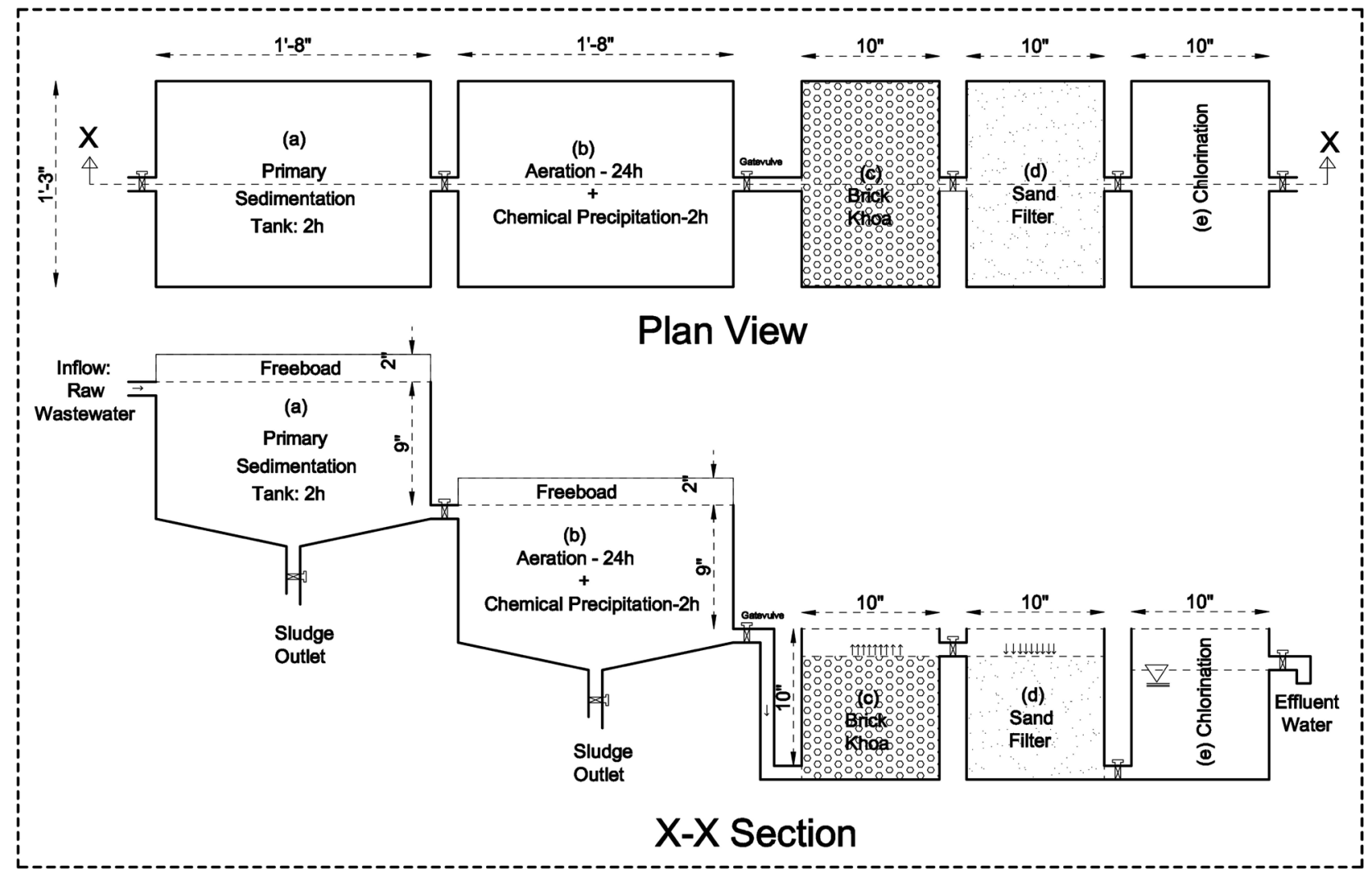

Figure 2. Instrumental setup and operation of developed treatment unit. 
was aerated for 24 hours before pouring the effluent into filter media so that oxygen can be mixed with wastewater properly. After aeration, an optimum alum dose $(70 \mathrm{mg} / \mathrm{l})$ put into aeration chamber to remove phosphorous. Then water passed through the up-flow roughing filter to catch the floc generated in chemical precipitation. After this, water again transferred into the sand filtration unit for nitrogen and bacteriological removal. Finally, a storage tank used to store treated effluent for chlorination before discharging. No power was used for the flow generation. Gravitational force controlled whole flow system. The entire setup is presented in Figure 2.

\section{Results and Discussion}

\subsection{Characterization of Raw Drainage Wastewater}

The results of different drain outlet's raw wastewater samples revealed the large number of polluting agents that are dumped every day in bodies of water without any treatment, which is alarming for the ecology of inland surface water. The chloride is the most dominant anion in wastewater generated in Khulna city irrespective of sampling station. The least dominant element is iron in the study area. The test results of raw drainage wastewater are presented in Table 2, which

Table 2. Physico-chemical characteristics of raw drainage wastewater.

\begin{tabular}{|c|c|c|c|c|c|c|c|c|}
\hline \multirow{2}{*}{ Water quality parameters } & \multirow{2}{*}{ Unit } & \multicolumn{3}{|c|}{ Sampling station (SS) } & \multirow{2}{*}{ Max. } & \multirow{2}{*}{ Min. } & \multirow{2}{*}{ Avg. } & \multirow{2}{*}{$\begin{array}{c}\text { Stand. } \\
\text { Dev. }\end{array}$} \\
\hline & & SS-1 & SS-2 & SS-3 & & & & \\
\hline $\mathrm{pH}$ & - & 7.27 & 7.35 & 7.49 & 7.49 & 7.27 & 7.37 & 0.09 \\
\hline DO & $\mathrm{mg} / \mathrm{l}$ & 0.74 & 0.79 & 0.69 & 0.79 & 0.69 & 0.74 & 0.04 \\
\hline $\mathrm{BOD}_{5}$ & $\mathrm{mg} / \mathrm{l}$ & 59 & 126 & 226 & 226 & 59 & 137.00 & 68.62 \\
\hline COD & $\mathrm{mg} / \mathrm{l}$ & 320 & 420 & 435 & 435 & 320 & 391.67 & 51.04 \\
\hline TDS & $\mathrm{mg} / \mathrm{l}$ & 1800 & 1950 & 2525 & 2525 & 1800 & 2091.67 & 312.47 \\
\hline TSS & $\mathrm{mg} / \mathrm{l}$ & 120 & 150 & 190 & 190 & 120 & 153.33 & 28.67 \\
\hline Hardness as $\mathrm{CaCO}_{3}$ & $\mathrm{mg} / \mathrm{l}$ & 148 & 128 & 116 & 148 & 116 & 130.67 & 13.20 \\
\hline Alkalinity as $\mathrm{CaCO}_{3}$ & $\mathrm{mg} / \mathrm{l}$ & 357 & 370 & 310 & 370 & 310 & 345.67 & 25.77 \\
\hline Chloride & $\mathrm{mg} / \mathrm{l}$ & 1325 & 1250 & 1570 & 1570 & 1250 & 1381.67 & 136.65 \\
\hline Nitrate & $\mathrm{mg} / \mathrm{l}$ & 12 & 11 & 17 & 17 & 11 & 13.33 & 2.62 \\
\hline Phosphate & $\mathrm{mg} / \mathrm{l}$ & 8.74 & 9.89 & 16.75 & 16.75 & 8.74 & 11.79 & 3.54 \\
\hline Sulfate & $\mathrm{mg} / \mathrm{l}$ & 156 & 154 & 180 & 180 & 154 & 163.33 & 11.81 \\
\hline Iron & $\mathrm{mg} / \mathrm{l}$ & 0.98 & 1 & 1.2 & 1.2 & 0.98 & 1.06 & 0.10 \\
\hline Electrical Conductivity & $\mu \mathrm{S} / \mathrm{cm}$ & 1785 & 1965 & 2145 & 2145 & 1785 & 1965 & 146.97 \\
\hline Color & Pt.Co & 478 & 503 & 615 & 615 & 478 & 532 & 59.57 \\
\hline Turbidity & NTU & 42 & 65 & 93 & 93 & 42 & 66.67 & 20.85 \\
\hline E. Coli & $\mathrm{Nos} / 100 \mathrm{ml}$ & 49,333 & 48,256 & 59,825 & 59,825 & 48,256 & 52,471 & 5218 \\
\hline Total Coliform & $\mathrm{Nos} / 100 \mathrm{ml}$ & 70,000 & 65,800 & 98,050 & 98,050 & 65,800 & 77,950 & 14,315 \\
\hline
\end{tabular}


shows a wide range of variation of drainage wastewater quality from different sampling stations of drain outlets of KCC. The values of raw wastewater parameter (SS-1, SS-2 and SS-3) presented are the average of three months (i.e. December, January and April) in each sampling station.

\subsection{Performance of Developed Laboratory-Scale Treatment Plant}

Performance of a developed laboratory-scale treatment plant (Table 3) varied depending on the parameters for which the plant was designed. Some parameters improved and satisfied the standard limit, whereas others did not. The removal of $\mathrm{BOD}_{5}, \mathrm{COD}$ and TDS were not very good, because aeration alone is not sufficient for their reduction. Maximum 53\% COD and $52 \% \mathrm{BOD}_{5}$ reduction were obtained for 24 hours aeration. Similarly, $24.7 \%$ and $60.0 \%$ reduction were attained for TDS and TSS respectively from 24 hours of aeration process. The application of alum and granular filter media accounted for a $90 \%$ and $96 \%$ reduction for fecal coliform and total coliform, respectively. Phosphate and nitrate reduction rate were $97 \%$ and $98.0 \%$, respectively, after treatment with the developed laboratory-scale treatment plant. Table 3 clearly stated that $\mathrm{BOD}_{5}, \mathrm{COD}$, and coliforms do not meet ECR'97 standard. So, the developed laboratory-scale

Table 3. Effluents quality of laboratory-scale treatment plant.

\begin{tabular}{cccccc}
\hline \multirow{2}{*}{ Water quality parameters } & Unit & \multicolumn{2}{c}{ Treated drainage wastewater } & *ECR'97 discharge \\
\cline { 3 - 5 } standard
\end{tabular}

*ECR'97: The Environmental Conservation Rules (1997) [14]. 
treatment plant needs to be modified for better $\mathrm{BOD}_{5}, \mathrm{COD}$, and Coliforms reduction efficiency. The values of effluent parameter (SS-1, SS-2 and SS-3) presented are the average of three months (i.e. December, January and April) in each sampling station.

\subsection{Modification of Laboratory-Scale Treatment Plant}

The laboratory-scale treatment plant could not remove all harmful contaminants from the wastewater as per standard requirement of ECR (1997). The modification of laboratory-scale treatment plant was made by activated sludge processing following filtration. The activated sludge process unit consisted of a high-quality plastic container as the primary clarifier, a reactor for the aeration chamber with an air blower, and a secondary clarifier with a pump for returning sludge. Three, five and seven days mean cell residence times were considered to activate the microorganisms in the activated sludge process unit. The effluents were passed through a granular filter media made from stone chips and sand (Figure 3 ). The filter media was constructed with locally available stone chips bed at the bottom of the container, along with a sand bed on its top. Both granular materials were well cleaned before use and each formed a uniform thick layer of 4-inch height. The bottoms of the filter chamber were kept empty for 2 inches for collection of sludge.

The effluent from the secondary clarifier traveled through the stone chips bed, followed by the sand bed, forming an up-flow of wastewater. The influent was

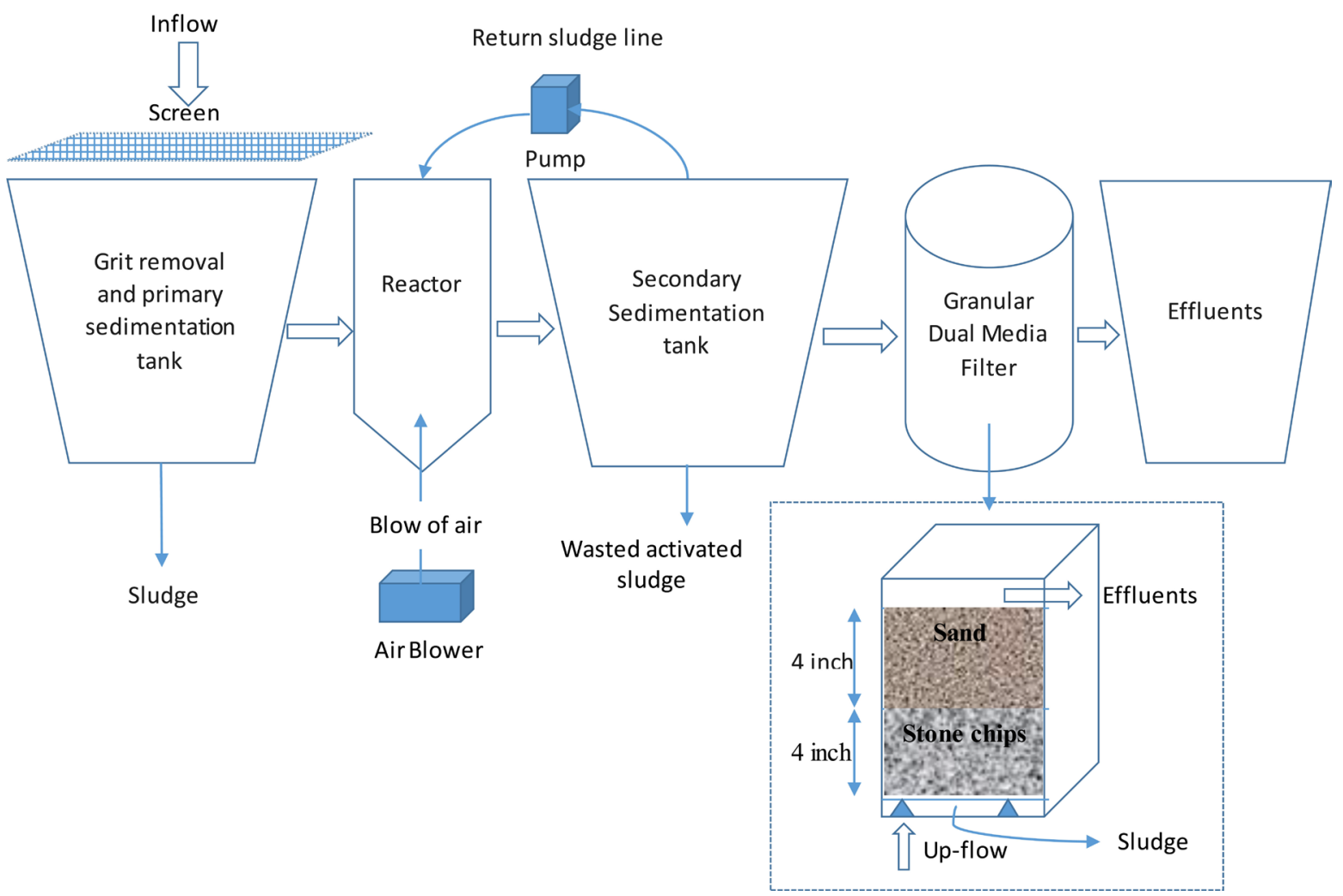

Figure 3. Flow diagram of modified treatment plant. 
passed through the screen $(5 \mathrm{~mm} \times 5 \mathrm{~mm})$ to strain off any coarse solids into the primary clarifier, which was also worked as a grit removal chamber. Then it was discharged to the reactor, an aeration chamber with a flow rate of $10 \mathrm{ml} / \mathrm{min}$. The hydraulic retention time in the aeration tank for this developed treatment unit was calculated as 4 hours. The wastewater was then transferred to the secondary clarifier for bacterial floc formation and settlement as active sludge. A return sludge line from the secondary clarifier was linked through a pump, which returned $5 \mathrm{ml} / \mathrm{min}$. of activated sludge to the reactor. A balance was made in the wastewater flow rate between the reactor and secondary clarifier. Another sludge line was formed in the secondary clarifier to discard a fixed amount of wastewater, with flow rate $0.05 \mathrm{ml} / \mathrm{min}$. to maintain the activated sludge process properly.

After the continuation of all these steps, the treated wastewater passed through a final filter media. Following activated sludge processing in a slow sand filter, the operating filtration rate varied between $0.1-0.3 \mathrm{~m}^{3} / \mathrm{m}^{2} / \mathrm{hr}$. The top layer of the sand becomes biologically active by the establishment of a microbial community on the top layer of the sand substrate. After treatment with an activated sludge process, the effluent needed to pass slowly through the coarse stone media and sand filter to improve the water quality. Instead of following the traditional down-flow method, the flow path was made upward through the stone chips bed layer and then sand bed. Finally, the effluents were disposed of through an outlet arrangement. This approach is recommended for longer filter runs with less operation and maintenance requirements [15].

\subsection{Performance of Laboratory-Scale Treatment Plant after Modification}

The performance of the laboratory-scale treatment plant after modification was monitored closely to determine the treatment efficiency of this system. The raw wastewater was collected from sampling station III. The test results from the raw wastewater and effluents from modified laboratory-scale treatment plant are illustrated in Table 4.

1) Biochemical Oxygen Demand $\left(\mathrm{BOD}_{5}\right)$

$\mathrm{BOD}_{5}$ is the most popular criteria parameter for organic pollution, useful to both wastewater and surface water. The raw wastewater sample has a $\mathrm{BOD}_{5}$ value of $226 \mathrm{mg} / \mathrm{l}$, which represents a lot of organic content present in the wastewater. After treatment of 3-days, 5-days and 7-days $\mathrm{BOD}_{5}$ levels decreased to $9.8 \mathrm{mg} / \mathrm{l}, 1.78 \mathrm{mg} / \mathrm{l}$ and $1.38 \mathrm{mg} / \mathrm{l}$, respectively. This shows that for 5 and 7 days, BOD $_{5}$ values fulfill the ECR (1997) standard limit of $50 \mathrm{mg} / \mathrm{l}$, but 3 days does not in the range (Table 4). Based on test result, it can be concluded that moderate concentration of organic matter is decomposed when wastewater kept more than 5 days into secondary settling tank.

2) Chemical Oxygen Demand (COD)

The COD test measures the organic matter present in industrial and municipal wastewater while $\mathrm{BOD}_{5}$ describes amount of oxygen required to decom- 
pose organic matter present in wastewater. The COD value of raw wastewater was $435 \mathrm{mg} / \mathrm{l}$ whereas after of 3-days, 5 -days and 7 -days, the values were measured at $192 \mathrm{mg} / \mathrm{l}, 96 \mathrm{mg} / \mathrm{l}$ and $32 \mathrm{mg} / \mathrm{l}$, respectively. The standard value of COD for industrial wastewater for disposal into surface water bodies is $200 \mathrm{mg} / \mathrm{l}$ (ECR, 97), which was fulfilled in all three cases. Calculation shows about $56 \%, 78 \%$ and 93\% removal efficiency measured from biological treatment of 3-days, 5-days and 7-days, respectively.

3) Total Dissolved Solids (TDS)

TDS is important to be considered in the calculation of irrigation water quality, because many of the toxic solid materials may be imbedded in the wastewater, which may cause harm to the plants [16]. Table 4 illustrates the final TDS values reported after treatment were $1667 \mathrm{mg} / \mathrm{l}, 705 \mathrm{mg} / \mathrm{l}$ and $590 \mathrm{mg} / \mathrm{l}$ for 3-days, 5-days and 7-days, respectively, which shows a positive trend of treatment of wastewater by the activated sludge system, whereas for raw wastewater the value was $2525 \mathrm{mg} / \mathrm{l}$. Thus, the average effluent concentrations were below the ECR (1997) standard limit (2100 mg/l).

4) Total Suspended Solids (TSS)

Suspended solids refer to small solid particles which remain in suspension in water as a colloid or due to the motion of the water. It is used as one indicator of water quality. The raw wastewater sample had a TSS concentration $190 \mathrm{mg} / \mathrm{l}$. After treatment, TSS levels in the final effluents decreased to $95 \mathrm{mg} / \mathrm{l}, 45 \mathrm{mg} / \mathrm{l}$ and $35 \mathrm{mg} / \mathrm{l}$ for 3-days, 5-days and 7-days, respectively. The standard limit of TSS concentration for disposal into inland water bodies is $150 \mathrm{mg} / \mathrm{l}$ (ECR, 1997). Thus, Table 4 shows that after treatment, the TSS concentration of effluents lie in the range of the standard limit.

\subsection{Comparison between Developed and Modified Laboratory-Scale Treatment Plant}

Table 5 illustrates that $49 \% \mathrm{BOD}_{5}$ reduction observed from laboratory-scale treatment plant, but after modification, the reduction efficiencies improved to 96\%, 99\% and 99\% for 3-days, 5-days and 7-days, which also satisfies the ECR (1997) standard limit. COD and TDS reduction efficiencies are $41 \%$ and $41 \%$ for the primarily developed laboratory-scale treatment plant, while $56 \%, 78 \%$ and 93\% COD and 34\%, 72\% and 77\% TDS reduction efficiencies were achieved from the modified treatment plant for 3-days, 5-days and 7-days, respectively.

Table 4. Effluent quality of modified laboratory-scale treatment plant.

\begin{tabular}{cccccccc}
\hline \multirow{2}{*}{ Water quality parameter } & Unit & Raw wastewater & \multicolumn{3}{c}{ Effluent } & \multirow{2}{*}{$\begin{array}{c}\text { ECR'97 discharge } \\
\text { standard }\end{array}$} \\
\cline { 5 - 6 } & & & 3-days & 5-days & 7-days & 50 \\
\hline BOD $_{5}$ & $\mathrm{mg} / 1$ & 226 & 9.8 & 1.78 & 1.38 & 500 \\
$\mathrm{COD}$ & $\mathrm{mg} / \mathrm{l}$ & 435 & 192 & 96 & 32 & 200 \\
$\mathrm{TDS}$ & $\mathrm{mg} / \mathrm{l}$ & 2525 & 1667 & 705 & 590 & 2100 \\
TSS & $\mathrm{mg} / \mathrm{l}$ & 190 & 95 & 45 & 35 & 150 \\
\hline
\end{tabular}


The result shows a positive trend of treatment efficiency of the wastewater treatment by the modified laboratory-scale treatment plant.

A large change was also noticed with solids after treatment in the laboratory-scale treatment plant after modification, specifically in TSS removal. In the case of the primarily developed treatment plant, the TSS removal efficiency was $55 \%$, whereas for the modified plant it rises to $82 \%$ for 7 -days treatment. Based on the findings, it can be summarized that, the laboratory-scale treatment plant after modification is more efficient than primarily developed treatment plant.

\subsection{Evaluation for Discharging into Surface Water Bodies and Agricultural Use}

Effluents from wastewater treatment plants (WWTP) are widely used in different industries e.g. agriculture, cooling towers, etc., and can enter directly into the ecosystem through discharging to surface or groundwater [17]. The discharge of wastewater from municipal, industrial, and agricultural areas is an issue of serious concern as it affects a river's ecology [18]. These widespread usages of treated wastewater compel legislators to set stringent rules and regulations with respect to WWTP effluents.

This study reveals that the effluent quality stated in Table 6 for discharging into surface water bodies mostly satisfies the standards. On the other hand, FAO standard for TDS (450 - $2000 \mathrm{mg} / \mathrm{l})$ and TSS (50 - $100 \mathrm{mg} / \mathrm{l})$ are also satisfy after

Table 5. Comparison of removal efficiency.

\begin{tabular}{ccccc}
\hline Water quality parameter $\begin{array}{c}\text { Primarily developed laboratory-scal } \\
\text { treatment plant (\% reduction) }\end{array}$ & $\begin{array}{c}\text { Modified laboratory-scale treatment } \\
\text { plant (\% reduction) }\end{array}$ \\
\hline BOD $_{5}$ & 49 & 96 & 99 & 99 \\
COD & 41 & 56 & 78 & 93 \\
TDS & 41 & 34 & 72 & 77 \\
TSS & 55 & 50 & 76 & 82 \\
\hline
\end{tabular}

${ }^{*}$ Data taken from effluent of sampling station III.

Table 6. Evaluation for discharging into surface water bodies and using irrigation purposes.

\begin{tabular}{|c|c|c|c|c|c|}
\hline $\begin{array}{c}\text { Water } \\
\text { quality } \\
\text { parameter }\end{array}$ & Unit & $\begin{array}{c}\text { Raw } \\
\text { wastewater }\end{array}$ & Effluent (7-days) * & $\begin{array}{c}\text { FAO (1985) } \\
\text { irrigation } \\
\text { standard [19] }\end{array}$ & $\begin{array}{l}\text { Bangladesh standard } \\
\text { limits for disposal in } \\
\text { surface water bodies } \\
\text { (ECR'97) }\end{array}$ \\
\hline $\mathrm{BOD}_{5}$ & $\mathrm{mg} / \mathrm{l}$ & 226 & 1.38 & $<100$ & 50 \\
\hline COD & $\mathrm{mg} / \mathrm{l}$ & 435 & 32 & - & 200 \\
\hline TDS & $\mathrm{mg} / \mathrm{l}$ & 2525 & 590 & $450-2000$ & 2100 \\
\hline TSS & $\mathrm{mg} / \mathrm{l}$ & 190 & 35 & $50-100$ & 150 \\
\hline
\end{tabular}

${ }^{\star}$ Effluents form modified laboratory-scale treatment plant. 
treatment by modified laboratory-scale treatment plant. The $\mathrm{BOD}_{5}$ of raw wastewater is high because the organic content in the city wastewater is usually high. After biological treatment for 7 days in the activated sludge processing unit following filtration, the $\mathrm{BOD}_{5}$ was reduced drastically to $1.38 \mathrm{mg} / \mathrm{l}$, which satisfies FAO water quality standards that are highly suitable for irrigation.

\section{Conclusions}

Based on the experimental results the following conclusion can be drawn:

1) Laboratory testing shows that the $\mathrm{BOD}_{5}$ and $\mathrm{COD}$ concentration of wastewater sample varied from $57-226 \mathrm{mg} / \mathrm{l}$ and $320-435 \mathrm{mg} / \mathrm{l}$, respectively, and the total dissolved solids (TDS) ranged from $1800-2525 \mathrm{mg} / \mathrm{l}$, which cross the standard range.

2) The laboratory-scale treatment units consisted of primary sedimentation followed by aeration, chemical precipitation and granular media filtration.

The mean removal efficiency for sampling station III is achieved $49 \%, 41 \%, 41 \%$, $55 \%, 97 \%, 95 \%$ and $90 \%$ for $\mathrm{BOD}_{5}$, COD, TDS, TSS, Phosphate, Nitrate and Coliform, respectively. But, for better $\mathrm{BOD}_{5}$, COD, TDS and TSS reduction, laboratory-scale treatment plant needs to be modified so that all effluent quality parameters could meet the ECR'97 standards for safe disposal into surface water bodies.

3) To get better quality of effluents, modification of primarily developed laboratory-scale treatment plant was done by activated sludge processes, followed by granular media filtration. The effluent from the modified treatment plant contained $\mathrm{BOD}_{5} 1.38-9.8 \mathrm{mg} / \mathrm{l}$, COD $32-192 \mathrm{mg} / \mathrm{l}$, TDS $590-1667 \mathrm{mg} / \mathrm{l}$ and TSS 35 - $95 \mathrm{mg} / \mathrm{l}$. Comparing with raw wastewater, about $96 \%$ - 99\% $\mathrm{BOD}_{5}, 56 \%$ - 93\% COD, 34\% - 77\% TDS and 50\% - 82\% TSS removal efficiency were recorded. After modification, the removal efficiency increases and satisfies the criteria for safe disposal into surface water bodies according to ECR'97 standards.

Finally, the effluent quality of modified laboratory-scale treatment plant is in the safe limit to use for irrigation purposes. The effluent can be used only in dry season, because this study was conducted during the months of December to April. Further studies need to understand the issues related to scaling up or commercial use of this laboratory-scale treatment plant.

\section{Acknowledgements}

The authors are deeply grateful to Technical Officer Mr. Sayed Ahsan Ali and Laboratory Technician Mr. Sardar Shahidul Alam who supported and motivated him throughout the whole study period.

\section{Conflicts of Interest}

The authors declare no conflicts of interest regarding the publication of this paper.

\section{References}

[1] Lazarova, V. and Bahri, A. (2005) Water Reuse For irrigation: Agriculture, Land- 
scapes, and Turf Grass. CRC Press, Boca Raton.

[2] Asano, T., Burton, L., Leverenz, L., Tsuchihashi, R. and Tchobanoglous, G. (2007) Water reuse: Issues, Technologies and Applications. McGraw-Hill, New York.

[3] UNESCO (United Nations Educational, Scientific and Cultural Organization) (2003) Water for People, Water for Life. United Nations/World water Assessment Programme, UNESCO, Berghahn Books, Paris, New York.

[4] Van der Hoek, W., Ul-Hassan, M., Ensink, J., Feenstra, S., Rashid-Sally, S., Aslam, R., Ali, N., Hussain, R. and Matsuno, Y. (2002) Urban Wastewater: A Valuable Resource for Agriculture. Research Report 63, IWMI, Colombo.

[5] Huibers, P. and Van Lier, B. (2005) Use of Wastewater in Agriculture: The Water Chain Approach. Irrigation and Drainage, 54, S3-S9.

https://doi.org/10.1002/ird.181

[6] IWMI (2006) Recycling Realities: Managing Health Risks to Make Wastewater an Asset. Water Policy Briefing 17, International Water Management Institute, Colombo.

[7] Qadir, M., Sharma, R., Bruggeman, A., Choukr-Allah, R. and Karajeh, F. (2007) Non-Conventional Water Resources and Opportunities for Water Argument to Achieve Food Security in Water Scarce Countries. Agricultural Water Management, 87, 2-22. https://doi.org/10.1016/j.agwat.2006.03.018

[8] BBS (2015) Population \& Housing Census-2011. Bangladesh Bureau of Statistics, 44.

[9] JICA (Japan International Cooperation Agency) (2010) Feasibility Study for Khulna Water Supply Improvement Project in the People's Republic of Bangladesh. Rural Development and Co-Operatives, Khulna Water Supply and Sewerage Authority, Draft Final Report for Ministry of Finance, Ministry of Local Government, Dhaka.

[10] BMD (2016) Normal Monthly Rainfall. Bangladesh Meteorological Department.

[11] Birks, R. and Hills, S. (2007) Characterization of Indicator Organisms and Pathogens in Domestic Drainage Water for Recycling. Environmental Monitoring Assessment, 129, 61-69. https://doi.org/10.1007/s10661-006-9427-y

[12] APHA (1992) Standard Methods for Examination of Water and Wastewater. 18th Edition, American Public Health Association, Washington DC.

[13] Rahman, M., Mridha, K. and Hassan, N. (2014) Evaluation of Urban-Wastewater Quality for Irrigation: A Case Study of Khulna City, Bangladesh. South Asian Water Studies, 4.

[14] ECR (1997) Ministry of Environment and Forest, Government of the People's Republic of Bangladesh. The Environment Conservation Rules, 205-207.

[15] Zouboulisa, A., Traskasa, G. and Samaras, P. (2007) Comparison of Single and Dual Media Filtration in A Full-Scale Drinking Water Treatment Plant. Desalination, 213, 334-342. https://doi.org/10.1016/j.desal.2006.02.102

[16] Matthess, G. (1982) The Properties of Groundwater. John Wiley and Sons, New York, 397.

[17] Iman, B. (2010) Disc-Filters for Tertiary Treatment of Wastewater at the Rya Wastewater Treatment Plant in Goteborg. Master of Science Thesis in the Master's programme Geo and Water Engineering, Department of Civil and Environmental Engineering, Division of Water Environment Technology, Chalmers University of Technology, Goteborg.

[18] Varol, M., Gokot, B., Bekleyen, A. and Sen, B. (2013) Geochemistry of the Tigris River Basin, Turkey: Spatial and Seasonal Variations of Major Ion Compositions 
and Their Controlling Factors. Quaternary International, 304, 22-32.

https://doi.org/10.1016/j.quaint.2012.12.043

[19] FAO (1985) Water Quality for Agriculture. Irrigation and Drainage Paper 29 Rev. 1, Food and Agricultural Organization, FAO, Rome, 174. 